\title{
Što određuje financijsku pismenost? U potrazi za relevantnim odrednicama
}

\author{
NIKOLA ERCEG * \\ ZVONIMIR GALIĆ \\ Odsjek za psihologiju \\ Filozofski fakultet Sveučilišta u Zagrebu \\ Zagreb, Hrvatska
}

MAJA VEHOVEC

Ekonomski institut, Zagreb

Zagreb, Hrvatska

\author{
Izvorni znanstveni rad \\ UDK: 336 \\ doi: 10.3935/rsp.v26i3.1541 \\ Primljeno: ožujak 2018.
}

\begin{abstract}
S obzirom na sve veću kompleksnost kao i povećanu potrebu za financijskim proizvodima, čini se kako su adekvatne razine financijske pismenosti neophodne. U Hrvatskoj postoji malo istraživanja odrednica financijske pismenosti građana. Stoga smo ovim istraživanjem željeli istražiti veći broj financijskih konstrukata u odnosu na prethodna istraživanja, kao i utvrditi važnost socio-demografskih činitelja u objašnjenju financijske pismenosti. Istraživanje je provedeno na reprezentativnom uzorku građana $R H(N=1049)$. Rezultati su pokazali da su socio-demografske varijable značajan prediktor financijske pismenosti, kao i njezinih komponenti znanja, stavova i ponašanja. U radu se raspravlja o važnosti različitih socio-demografskih karakteristika, te zaključuje da, iako značajne, socio-demografske varijable vjerojatno nisu najvažnije odrednice financijskih ishoda. Stoga se predlaže veći naglasak na dodatnim, psihološkim karakteristikama kao potencijalnim determinantama financijskih ishoda.
\end{abstract}

Ključne riječi: financijska pismenost, financijsko znanje, financijski stavovi, financijska ponašanja.

\section{UVOD}

Sa sniženom socijalnom sigurnosti, povećanjem osobne odgovornosti, kao i očekivanog životnog vijeka, potrebe pojedinaca za različitim financijskim proizvodima postaju sve izraženije (Habschick, Seidl i Evers, 2007.). U isto vrijeme, sve veći je broj dostupnih proizvoda, kao i dostupnih informacija te distribucijskih kanala pa ti proizvodi postaju sve kompleksniji i nedostupniji »običnim« ljudima. U ovakvoj situaciji, čini se da je određena razina financijske pismenosti koja uključuje ne samo znanja, već i dodatne aspekte poput stavova i različitih ponašanja, neophodna kako bi se pojedinac uopće mogao snaći u financijskom svijetu te donositi odluke koje ce dovesti do pozitivnih financijskih ishoda.

\footnotetext{
* Nikola Erceg, Odsjek za psihologiju, Filozofski fakultet Sveučilišta u Zagrebu / Department of Psychology, Faculty of Humanities and Social Sciences of Zagreb, University of Zagreb, Ivana Lučića 3, 10000 Zagreb, Hrvatska/Croatia, nerceg@ffzg.hr
} 
Osim za dobrobit pojedinca, razina financijske pismenosti važna je i za cijelo društvo. Primjerice, Svjetska banka u svom Dijagnostičkom pregledu zaštite potrošača i financijske pismenosti (2010.) navodi da je svrha podizanja financijske pismenosti približavanje financijskih usluga ugroženim kućanstvima s nižim primanjima, ali i osiguravanje dugoročne financijske stabilnosti socijalnih sustava. Prema tome, nedostatak financijske pismenosti može imati negativan utjecaj ne samo na osobnu financijsku dobrobit, već i na širu ekonomiju (Alsemgeest, 2015.). Tako, Habschik, Seidl i Evers (2007.) navode kako neadekvatna alokacija osobnih financija uzrokuje lošije financijsko stanje i ishode, a to povećava javne troškove u vidu socijalnih davanja i troškova zdravstva.

U Hrvatskoj postoji vrlo malo istraživanja razvijenosti i odrednica financijske pismenosti građana (npr. Vehovec, Rajh i Škrebin Kirbiš, 2015.; Škreblin Kirbiš, Vehovec i Galić, 2017.). Istraživanjem opisanim u ovom radu htjeli smo ostvariti dva glavna cilja. Prvo, nastojali smo proširiti definiciju financijske pismenosti, odnosno zahvatiti veći broj konstrukata koji spadaju $\mathrm{u}$ ovu domenu, u usporedbi s ranijim istraživanjima. Konkretno, dosadašnja istraživanja financijske pismenosti u Hrvatskoj bila su ograničena na OECD-ovu (Organizacija za ekonomsku suradnju i razvoj) mjeru financijske pismenosti koja uključuje objektivno financijsko znanje, financijske stavove i financijsko ponašanje. U našem istraživanju, osim objektivnog financijskog znanja, želimo istražiti i subjektivno, odnosno samoprocijenjeno financijsko znanje, jer se ono u nizu istraživanja pokazalo važnijom odrednicom financijskih ponašanja (Aertsens i sur., 2011.; Pieniak, Aertsens i Verbeke, 2010.). Nadalje, s obzirom da OECD-ova mjera zahvaća ograničen raspon financijskih ponašanja, nastojali smo ovu domenu, na reprezentativnom uzorku građana $\mathrm{RH}$, zahvatiti s nizom dodatnih čestica. Drugo, u ovom istraživanju želimo utvrditi opću važnost socio-demografskih činitelja u objašnjenju financijske pismenosti pojedinaca te usporediti važnost pojedinačnih socio-demografskih odrednica u predviđanju opće financijske pismenosti i njenih subkomponenti.

U nastavku rada, dat ćemo pregled različitih definicija i konceptualizacija financijske pismenosti, opisati najvažnije zaključke inozemnih i domaćih istraživanja financijske pismenosti, te specificirati ciljeve trenutnog istraživanja. U drugom dijelu detaljnije ćemo opisati metodologiju, uključujući uzorak, varijable i postupak, nakon čega ćemo opisati glavne rezultate trenutnog istraživanja. Rad zaključujemo diskusijom u kojoj raspravljamo o implikacijama i važnosti predočenih rezultata, kao i nedostacima našeg istraživanja.

\section{DEFINIRANJE I \\ KONCEPTUALIZACIJA FINANCIJSKE PISMENOSTI}

Čini se da u literaturi još uvijek nema jedinstvene i opće prihvaćene definicije financijske pismenosti. Vjerojatno je to dijelom i posljedica toga što ne postoji ni slaganje oko strukture i opsega ovog konstrukta. Primjerice, Hung, Parker i Yoong (2009.) utvrdili su kako se financijska pismenost $\mathrm{u}$ literaturi definira kao: (1) specifična vrsta znanja, (2) sposobnost ili vještina upotrebe znanja, (3) percipirana razina znanja, (4) dobra financijska ponašanja te (5) financijsko iskustvo. U novije vrijeme postoji slaganje niza autora (npr. Huston, 2010.; Hung, Parker i Yoong, 2009.; Remund, 2010.) da se radi o složenom konstruktu koji predstavlja kombinaciju financijskog znanja i sposobnosti adekvatnog korištenja tog znanja angažiranjem u primjerenim i pozitivnim financijskim ponašanjima. Drugim riječima, financijsko znanje samo po sebi nije isto što i financijska pismenost; uz znanje su važne i karakteristike pojedinca potrebne da se to znanje pretoči u adekvatno ponašanje. 
Organizacija za ekonomsku suradnju i razvoj (OECD) ide još korak dalje u definiranju financijske pismenosti, pa uz znanja i ponašanja, ističe $i$ važnost financijskih stavova. Stoga se financijska pismenost, kako je OECD konceptualizira, može definirati kao kombinacija znanja, stavova i ponašanja potrebnih za donošenje ispravnih financijskih odluka koje u konačnici dovode do većeg financijskog blagostanja (Vehovec i sur., 2015.). Kako zaključuju Atkinson i Messy (2012.), ukoliko pojedinac ima negativne stavove prema štednji za budućnost, ili daje prioritet zadovoljenju trenutnih, kratkoročnih potreba, manje je vjerojatno da će taj pojedinac štedjeti novac ili raditi dugoročnije financijske planove, bez obzira na objektivnu razinu njegovog/njenog financijskog znanja.

Kako u našem radu koristimo podatke iz istraživanja Hrvatske narodne banke (HNB) koje je definiralo financijsku pismenost prema OECD uputama (OECD/INFE, 2015.), u skladu s tim financijsku pismenost definiramo kao kombinaciju financijskih znanja, financijskih stavova i financijskog ponašanja. Na taj način, osim istraživanja financijske pismenosti kao jedinstvenog konstrukta, moguće je istraživati i svaku sastavnicu pojedinačno. Također, moguće je i kroskulturalno uspoređivati financijsku pismenost kao i pratiti njezin razvoj unutar određene države uspoređujući rezultate s dosadašnjim izvještajima OECD-a (vidi Atkinson i Messy, 2012.).

\section{Dosadašnji rezultati istraživanja financijske pismenosti}

Jedan od najkonzistentnijih empirijskih nalaza je taj da su financijsko znanje i pismenost građana u pravilu niski. Primjerice, Lusardi i Mitchell (2014.) u opsežnom pregledu literature navode da je financijsko znanje građana SAD-a vrlo nisko. Autorice su konstruirale tri pitanja u svrhu mjerenja financijskog znanja, a ta pitanja su zbog svoje jednostavnosti postala standard u međuna- rodnim istraživanjima financijskog znanja (tzv. »velika tri pitanja«, Hastings, Madrian i Skimmyhorn, 2013.; prva tri pitanja u Tablici A u dodatku). Kako navode, samo trećina starije populacije bila je u stanju točno odgovoriti na sva tri pitanja, a puno boljima nisu se pokazali ni srednjoškolci i studenti.

Na slične zaključke o nisko razvijenoj financijskoj pismenosti došle su i Atkinson i Messy (2012.) u radu u kojem predstavljaju rezultate pilot istraživanja OECD-ove Međunarodne mreže za financijsku edukaciju (eng. International network on financial education - INFE) provedenog u 14 različitih zemalja. Autorice navode da je prosječan rezultat financijske pismenosti u tom istraživanju bio samo 13,7 bodova od mogućih 22, na osnovi čega zaključuju da je financijska pismenost generalno na niskim razinama. Slične rezultate pokazalo je i kasnije istraživanje (Atkinson, Monticone i Messy, 2016.) provedeno u 30 zemalja među kojima je bila i Hrvatska, u kojemu je prosječna razina financijske pismenosti bila 13,2 od mogućih 21 boda. Uspoređujući rezultate iz 30 različitih zemalja, čini se da su hrvatski građani među financijski najmanje pismenima. Naime, prosječan rezultat financijske pismenosti hrvatskih ispitanika bio je 12, a samo su dvije države, Bjelorusija i Poljska, postigle lošiji rezultat od nas (Atkinson i sur., 2016.). Ovakvi rezultati su zabrinjavajući i ukazuju na potrebu neke vrste intervencija u svrhu poboljšavanja financijskih znanja, stavova i ponašanja.

Osim same razine, vrlo je važno pitanje ključnih odrednica financijske pismenosti. U svom preglednom radu, Lusardi i Mitchell (2014.) navode da se financijska pismenost razlikuje s obzirom na dob, spol, obrazovanje, prihode i mjesto boravka pojedinca. Što se tiče dobi, čini se da je odnos između nje i financijske pismenosti nelinearan; pokazalo se da je pismenost znatno niža među mlađom i starijom populacijom u odnosu na pojedince srednje dobi. Jedan od najkonzistentnijih nalaza $\mathrm{u}$ istraživanjima financijske pismenosti su spolne razlike. 
Naime, istraživanja uglavnom pokazuju da muškarci postižu više rezultate od žena, a razlika je vidljiva i na lakšim i na težim pitanjima financijskog znanja. Također, rezultati OECD/INFE (2016.) istraživanja pokazuju da su spolne razlike prisutne $u$ većini zemalja; u prosjeku je $61 \%$ muškaraca postiglo tzv. minimalni ciljni rezultat (pet od sedam točnih odgovora) u odnosu na $51 \%$ žena. Kako navode Chen i Volpe (2002.), čini se da ova razlika nije posljedica nekih drugih čimbenika s obzirom da ostaje značajna i kad se kontrolira za faktore poput područja studija, ocjena, radnog iskustva, dobi, rase, nacionalnosti i dohotka. Autori smatraju da su spolne razlike u financijskoj pismenosti rezultat toga što muškarci iskazuju veću zainteresiranost i samopouzdanje vezano uz osobne financije u odnosu na žene, a ovaj zaključak podupiru i nalazi Bucher-Koenena i sur. (2016.) da su žene znatno nesigurnije u svoje odgovore i na financijska pitanja češće od muškaraca odgovaraju s »ne znam«. Financijska pismenost pokazala se povezanom i s razinom obrazovanja. Sudionici s višim stupnjem formalnog obrazovanja u prosjeku su postizali bolje rezultate na testovima financijske pismenosti, čak i nakon što su se u obzir uzele razlike u kognitivnim sposobnostima. Također, čini se da i radni status i primanja igraju značajnu ulogu u financijskoj pismenosti. Naime, nezaposleni pojedinci i oni s nižim primanjima u prosjeku postižu niže rezultate od zaposlenih ili pojedinaca $\mathrm{s}$ višim primanjima (Lusardi i Mitchell, 2014.).

Dosadašnja istraživanja financijske pismenosti u Hrvatskoj bavila su se različitim korelatima financijske pismenosti. Primjerice, financijska pismenost pokazala se povezanom s pozitivnijim stavovima prema mirovinskom planiranju i većom vjerojatnosti mirovinske štednje (Barbić, Palić i Bahovec, 2016.), kao i s uspješnošću u upravljanju osobnim financijama (Cvrlje, 2014.). Također, Barbić, Lučić i Chen (2019.) su u nedavnom istraživanju pokazali da je financijska pismenost važna odrednica odgo- vornog financijskog ponašanja (iako znatno slabija od stavova i percipirane osobne kontrole nad ponašanjem). Međutim, istraživanja koja ispituju odrednice financijske pismenosti još uvijek su vrlo rijetka. Vehovec i sur. (2015.) ispitali su povezanost određenih socio-demografskih karakteristika i financijske pismenosti, dok su se, koristeći istu bazu podataka, Škreblin Kirbiš i sur. (2017.) detaljnije pozabavili spolnim razlikama. Rezultati dobiveni na hrvatskom uzorku uglavnom su u skladu s onima iz strane literature. Vehovec i sur. (2015.) pokazali su da postoje spolne i dobne razlike samo u općoj financijske pismenosti (suma rezultata na znanju, stavovima i ponašanjima) i subkomponenti financijskog znanja, ali ne i u subkomponentama financijskih stavova i ponašanja. $\mathrm{Na}$ navedenim mjerama muškarci i stariji sudionici postižu bolje rezultate od žena i mlađih sudionika. Spolne razlike u financijskoj pismenosti potvrdili su i Bahovec, Barbić i Palić (2017.) u svom istraživanju. Podjednak obrazac pokazao se i za odnos radnog statusa i veličine mjesta stanovanja s financijskom pismenošću. Naime, zaposleni sudionici kao i sudionici iz većih gradova postizali su bolje rezultate na općoj financijskoj pismenosti i subkomponenti financijskog znanja, ali ne i financijskim stavovima i ponašanjima. Konačno, razina obrazovanja i prihodi kućanstva pokazali su se povezanima i s opcom financijskom pismenosti, financijskim znanjem, ali i financijskim ponašanjima. Obrazovaniji sudionici i oni s većim prihodima bili su generalno financijski pismeniji, pokazivali bolje financijsko znanje $i$ adekvatnija ponašanja od manje obrazovanih sudionika i sudionika s nižim primanjima. Slične rezultate dobili su i Bujan, Cerović i Samaržija (2016.) koji su pokazali da se razina financijske pismenosti povećava s dobi, razinom obrazovanja i visinom prihoda, dok je mirovinska pismenost, kao komponenta financijske pismenosti, ipak pokazala nešto drugačiji obrazac povezanosti sa socio-demografskim faktorima. Naime, dok je u 
istraživanju Škreblin Kirbiš, Tomić i Vehovec (2011.) mirovinska pismenosti bila pozitivno povezana s visinom osobnih primanja i stupnjem obrazovanja, dob i spol sudionika nisu se pokazali značajnim odrednicama te kriterijske varijable.

\section{Naše istraživanje}

Ministarstvo financija Republike Hrvatske donijelo je 2014. godine Nacionalni strateški okvir financijske pismenosti (Narodne novine, 2015.) s ciljem stvaranja temelja za sustavnu i sveobuhvatnu integraciju financijskog obrazovanja u obrazovne procese. Dokument kao glavne ciljeve postavlja zaštitu pojedinaca i povećanje njihove financijske pismenosti, a što bi se trebalo realizirati kroz financijske edukacije namijenjene podizanju financijskog znanja kao preduvjeta za sveobuhvatniju financijsku pismenost. Međutim, istraživanja odrednica financijske pismenosti na kojima bi se trebale temeljiti financijske edukacije u RH su rijetka. U ovom istraživanju imali smo dva cilja. Prvo, nastojali smo replicirati nalaze Vehovec i sur. (2015.). Iako ovo nije jedino istraživanje financijske pismenosti u Hrvatskoj, razlog zbog kojeg smo se odlučili na repliciranje rezultata upravo ovog istraživanja leži u činjenici da su Vehovec i sur. (2015.) na jednak način kao i mi mjerili financijsku pismenost. Drugim riječima, kao i u ovom istraživanju, i u njihovom istraživanju izmjerene su tri različite komponente financijske pismenosti (znanje, stavovi i ponašanje), kao i opći rezultat financijske pismenosti, što nam omogućuje direktnu usporedbu naših rezultata s rezultatima navedenog istraživanja. Međutim, osim same replikacije, pokušali smo i proširiti zaključke spomenutog istraživanja. Prvo, proširili smo raspon varijabli koje spadaju u indikatore financijske pismenosti, mimo onih koje su zahvaćene uobičajenom OECD-ovom mjerom, na mjere subjektivnog financijskog znanja i dodatne mjere financijskih ponašanja. Smatramo da je posebnu pažnju u istraživanjima financijske pismenosti potrebno posvetiti samoprocijenjenom financijskom znanju kao važnoj odrednici financijskih ponašanja (Aertsens i sur., 2011.; Pieniak, Aertsens i Verbeke, 2010.), posebno u svjetlu činjenice da se ljudi u pravilu ponašaju sukladno subjektivnim, a ne objektivnim razinama znanja. Stoga je potrebno istražiti njihovu sukladnost i razlike u njihovim odrednicama.

Drugo, prethodna istraživanja pokazala su da postoji određena povezanost između socio-demografskih varijabli i financijske pismenosti. Međutim, iako socio-demografske varijable objašnjavaju statistički značajan dio varijance u financijskoj pismenosti, nije potpuno jasno koliki je točno taj dio jer je, primjerice, istraživanje Vehovec i sur. (2015.) vezu između socio-demografskih varijabli i financijske pismenosti mjerene OECD upitnikom zahvaća na univarijatnoj razini. Drugim riječima, postoji mogućnost da socio-demografske varijable nisu toliko bitne odrednice financijske pismenosti, odnosno da postoje neki drugi faktori koji objašnjavaju individualne razlike u financijskoj pismenosti (npr. Brown i Taylor, 2014.; Xu, Beller, Roberts i Brown, 2015.; Willis, 2008.). Stoga smo u ovom istraživanju kvantificirali postotak individualnih razlika u financijskoj pismenosti i njenim komponentama koji je moguće objasniti ključnim socio-demografskim varijablama. Na temelju dosadašnjih istraživanja, pretpostavljali smo da će, u terminima veličine efekta (Cohen, 1988.), značajan dio individualnih razlika u financijskoj pismenosti i njezinim komponentama ostati neobjašnjen glavnim sociodemografskim varijablama. Nadalje, zbog činjenica da su veze socio-demografskih varijabli i financijske pismenosti analizirane na univarijatnoj razini, važnost nekih socio-demografskih odrednica za financijsku pismenost može biti bolje objašnjena njihovom povezanosti s trećim varijablama. Primjerice, razlike u financijskoj pismenosti ovisno o regiji ili veličini mjesta iz koje ispitanici dolaze (Vehovec i sur., 2015.) možda mogu biti objašnjene vezom obje te varijable s razinom prihoda kućanstva 
ili razinom obrazovanja sudionika. U ovom radu, povezanosti socio-demografskih varijabli s financijskom pismenosti tretirali smo multivarijatno, odnosno uz kontrolu drugih ostalih varijabli. Osim toga, koristeći analizu dominantnosti (Budescu, 1993.; LeBreton i Tonidandel, 2008.), nastojali smo za svaku od socio-demografskih varijabli utvrditi koliko je važna za financijsku pismenost, ali i njene pojedinačne subkomponente.

\section{METODOLOGIJA}

\section{Uzorak}

U istraživanju je sudjelovalo 1049 sudionika koji predstavljaju reprezentativan uzorak na nacionalnoj razini po dobi, spolu, regiji, veličini naselja te obrazovanju (Ipsos, 2015.). Detaljna struktura uzorka u ovisnosti o različitim sociodemografskim karakteristikama prikazana je u Tablici 1.

\section{Tablica 1.}

Struktura uzorka s obzirom na spol, dob, prihode kućanstva, obrazovanje, radni status $i$ mjesto stanovanja

\begin{tabular}{|c|c|c|}
\hline \multirow{2}{*}{ Spol } & $\mathrm{M}$ & $48,7 \%$ \\
\hline & $\mathrm{F}$ & $51,3 \%$ \\
\hline \multirow{7}{*}{ Dob } & $18-19$ & $4,8 \%$ \\
\hline & $20-29$ & $15,6 \%$ \\
\hline & $30-39$ & $14,5 \%$ \\
\hline & $40-49$ & $23,3 \%$ \\
\hline & $50-59$ & $14,2 \%$ \\
\hline & $60-69$ & $17,8 \%$ \\
\hline & $70-79$ & $9,8 \%$ \\
\hline \multirow{3}{*}{ Prihodi } & $<3750 \mathrm{HRK}$ & $28,5 \%$ \\
\hline & $3750 \mathrm{HRK}-6250 \mathrm{HRK}$ & $40,4 \%$ \\
\hline & $>6250 \mathrm{HRK}$ & $31,1 \%$ \\
\hline \multirow{3}{*}{ Obrazovanje } & Osnovna škola & $22,8 \%$ \\
\hline & Srednja škola & $57,3 \%$ \\
\hline & Više/visoko obrazovanje & $19,9 \%$ \\
\hline \multirow{2}{*}{ Radni status } & Nezaposleni & $50,7 \%$ \\
\hline & Zaposleni & $49,3 \%$ \\
\hline \multirow{4}{*}{$\begin{array}{l}\text { Veličina } \\
\text { naselja }\end{array}$} & $<2000$ stanovnika & $38,2 \%$ \\
\hline & $2001-10000$ & $15,9 \%$ \\
\hline & $10001-100000$ & $20,3 \%$ \\
\hline & > 100001 stanovnika & $25,5 \%$ \\
\hline
\end{tabular}

\section{Mjere}

\section{Mjere financijske pismenosti}

U našem istraživanju koristili smo OECD mjeru financijske pismenosti (Atkinson i Messy, 2012.) koja uključuje subskale financijskog znanja, financijskih stavova i financijskih ponašanja te dodatne čestice koje zahvaćaju samoprocijenjeno financijsko znanje i dodatne aspekte financijskih ponašanja koje nisu pokriveni OECD upitnikom.

OECD financijsko znanje - Upitnik financijskog znanja, u skladu s OECD/INFE sugestijama, sastoji se od sedam zadataka koji pokrivaju širok spektar financijskih tema poput jednostavnih i složenih kamata, rizika i povrata uloženog i inflacije. Primjerice, jedno od pitanja je »Zamislite da ste prijatelju posudili $\mathrm{X}$ novaca, a on vam sutradan vrati X količinu novaca. Koliku kamatu je vaš prijatelj platio na ovaj zajam? Za svaki odgovor sudionik dobiva jedan bod ukoliko je odgovor točan, a nula bodova ukoliko je odgovor netočan. Dakle, na ovoj mjeri je mogući raspon rezultata od nula do sedam. Svi zadaci financijskog znanja zajedno s točnim odgovorima prikazani su u Tablici A u dodatku.

OECD financijski stavovi-sastoji se od tri tvrdnje: 1) »Nastojim živjeti za danas, a sutra kako bude.«; 2) »Nalazim veće zadovoljstvo u trošenju novca negoli u dugoročnoj štednji.«; 3) »Novac postoji da bi se trošio.«Zadatak sudionika bio je na skali od 5 stupnjeva procijeniti stupanj svog slaganja sa svakom od tvrdnji, gdje 1 predstavlja potpuno slaganje, a 5 potpuno neslaganje s tvrdnjom. Ukupni rezultat računa se kao prosjek ove tri čestice pa je mogući raspon individualnih rezultata na ovoj mjeri od jedan od pet, pri čemu su odgovori sudionika rekodirani tako da viši rezultati ukazuju na pozitivnije stavove prema štednji, odnosno višu financijsku samokontrolu.

OECD financijska ponašanja - ova mjera predstavlja kompozit od osam ra- 
zličitih ponašanja iz financijske domene, poput plaćanja računa na vrijeme, praćenja vlastitih financija ili štednje. Za većinu ponašanja pokrivenih ovom mjerom, sudionici su dobili jedan bod ukoliko su iskazivali pozitivno financijsko ponašanja. U suprotnom, dodijeljeno im je nula bodova. Samo je jedna čestica ocjenjivana na dvije razine, pa su u tom slučaju sudionici dobili jedan ili dva boda ovisno o razini pozitivnog financijskog ponašanja koju su iskazivali. U konačnici, rezultat na ovoj mjeri predstavlja zbroj bodova na pojedinim česticama, a on može varirati između nula i devet. Sve čestice financijskog ponašanja i načini bodovanja prikazani su u Tablici B u dodatku.

Financijska pismenost - konačno, financijska pismenost predstavlja kombiniranu mjeru tri aspekta: znanja, stavova i ponašanja. Ukupan rezultat na mjeri financijske pismenosti dobiva se jednostavnim zbrajanjem ukupnih rezultata na mjerama financijskog znanja, stavova i ponašanja. Dakle, u ovisnosti o rezultatima na navedenim mjerama, svaki sudionik je na mjeri financijske pismenosti mogao postići rezultat između 0 i 21.

Samoprocijenjeno financijsko znanjezadatak sudionika bio je procijeniti vlastito financijsko znanje na skali od pet stupnjeva gdje 1 znači »vrlo nisko financijsko znanje«, a 5 »vrlo visoko financijsko znanje.«

\section{Dodatne mjere financijskih ponašanja}

Osim navedenih čestica financijskih stavova, OECD/INFE istraživanje sastojalo se i od čestica koje su zahvaćale dodatna financijska ponašanja. Primjerice, neke čestice odnose se na ponašanja vezana uz trošenje novca, plaćanje računa, štednju i investiranje ili dugoročno financijsko planiranje. Kako bi pokušali proširiti mjere financijskih ponašanja, u ovom istraživanju nad navedenim česticama proveli smo faktorsku analizu. Analiza je pokazala da se čestice mogu najbolje objasniti pomoću dva faktora, a pripadajuće čestice svakog faktora pokazale su zadovoljavajuća zasićenja i adekvatnu unutarnju konzistentnost. Prvi izlučeni faktor nazvali smo »financijski odgovornim ponašanjem«, dok smo drugi nazvali »financijskim planiranjem $\ll$. Sva faktorska zasićenja bila su viša od sugerirane donje granične vrijednosti od $\lambda=$ 0,32 (Tabachnick i Fidell, 2013.; najniže faktorsko zasićenje u našem slučaju bilo je $\lambda=0,70)$. Također, Kaiser-Meyer-Olkin vrijednost bila je zadovoljavajuća $(K M O=$ $0,73)$, što ukazuje na dovoljno visok udio komunaliteta u odnosu na unikvitet te opravdanost korištenja postupka faktorske analize (Kaiser, 1974.).

Financijski odgovorno ponašanje - ova skala sastoji se od četiri čestice: 1$) »$ Vodim računa o vlastitim financijskim poslovima.«; 2) »Prije nego nešto kupim, pažljivo razmotrim mogu li si to priuštiti.«; 3) »Svoje račune plaćam na vrijeme.« i 4) »Često brinem o pokrivanju svakodnevnih životnih troškova.« Ispitanici su procjenjivali svoje slaganje sa svakom od navedenih tvrdnji na skali od pet stupnjeva, gdje 1 predstavlja potpuno neslaganje, dok 5 predstavlja potpuno slaganje s tvrdnjom. Ukupan rezultat računa se na način da se zbroje procjene na svakoj pojedinoj čestici, a zbroj podijeli s brojem čestica. Dakle, teoretski je svaki sudionik mogao postići rezultat između nula i pet, gdje viši rezultati ukazuju na odgovornije financijsko ponašanje.

Financijsko planiranje - Drugi faktor nazvali smo »financijsko planiranje « jer se sastoji od sljedeće dvije čestice: 1 ) »Spreman sam riskirati određenu količinu vlastitog novca kad štedim ili ulažem.« i 2) »Postavljam dugoročne financijske ciljeve i trudim ih se postići.« Skala procjene i računanje ukupnog rezultata jednaki su kao i za prethodnu mjeru, a viši rezultati ukazuju na veću sklonost financijskom planiranju. 


\section{Socio-demografske varijable}

Kao sociodemografske varijable uključili smo dob, spol, obrazovanje, prihode kućanstva, radni status i broj stanovnika mjesta u kojem sudionik živi. Kodiranje socio-demografskih varijabli prikazano je u Tablici 1. Primjerice, dob smo kodirali tako što smo najnižoj dobnoj kategoriji (< 19 godina) dodijelili vrijednost 1 , a najvišoj (70 - 79 godina) vrijednost 7 . Slično tome, prihode smo kodirali tako da je najnižoj kategoriji (<3 750 kuna) dodijeljena vrijed- nost 1, a najvišoj (> 6250 kuna) vrijednost 3. Na ovakav način kodirane su i varijable veličine naselja i obrazovanja. Spol i radni status bile su dihotomne varijable pri čemu je kategorijama muškarci i nezaposleni dodijeljena vrijednost 1 , a kategorijama žene i zaposleni vrijednost 2 .

U Tablici 2. prikazane su srednje vrijednosti rezultata na svim mjerenim varijablama u ovisnosti o socio-demografskim karakteristikama.

Tablica 2.

Srednje vrijednosti rezultata na mjerama različitih komponenata financijske pismenosti u ovisnosti o sociodemografskim karakteristikama

\begin{tabular}{|c|c|c|c|c|c|c|c|c|}
\hline & & $\begin{array}{c}\text { Financij- } \\
\text { ska } \\
\text { pisme- } \\
\text { nost }\end{array}$ & $\begin{array}{c}\text { Financij- } \\
\text { sko zna- } \\
\text { nje }\end{array}$ & $\begin{array}{c}\text { Financij- } \\
\text { ski sta- } \\
\text { vovi }\end{array}$ & $\begin{array}{l}\text { Financij- } \\
\text { sko po- } \\
\text { našanje }\end{array}$ & $\begin{array}{c}\text { Samo- } \\
\text { procjena } \\
\text { znanja }\end{array}$ & $\begin{array}{c}\text { Finan- } \\
\text { cijska } \\
\text { odgovor- } \\
\text { nost }\end{array}$ & $\begin{array}{c}\text { Finan- } \\
\text { cijsko } \\
\text { planira- } \\
\text { nje }\end{array}$ \\
\hline \multirow{2}{*}{ Spol } & $\mathrm{M}$ & 11,28 & 4,35 & 2,93 & 4,00 & 2,97 & 3,69 & 3,17 \\
\hline & $\check{Z}$ & 11,35 & 4,35 & 2,92 & 4,09 & 2,92 & 3,79 & 3,19 \\
\hline \multirow{3}{*}{ Dob } & Mlađa & 10,45 & 4,15 & 2,67 & 3,66 & 2,80 & 3,51 & 3,11 \\
\hline & Srednja & 11,83 & 4,55 & 2,98 & 4,30 & 3,15 & 3,76 & 3,28 \\
\hline & Starija & 10,92 & 4,18 & 2,96 & 3,78 & 2,72 & 3,81 & 3,00 \\
\hline \multirow{3}{*}{ Obrazovanje } & Osnovna & 9,99 & 3,92 & 2,84 & 3,23 & 2,50 & 3,64 & 2,84 \\
\hline & Srednja & 11,44 & 4,42 & 2,90 & 4,12 & 2,99 & 3,77 & 3,22 \\
\hline & Viša & 12,37 & 4,69 & 3,04 & 4,64 & 3,39 & 3,78 & 3,45 \\
\hline \multirow{3}{*}{$\begin{array}{l}\text { Mjesečna } \\
\text { primanja }\end{array}$} & $<3750 \mathrm{kn}$ & 10,18 & 3,90 & 2,91 & 3,37 & 2,50 & 3,71 & 2,77 \\
\hline & $3750-6750$ & 11,36 & 4,32 & 2,97 & 4,07 & 2,95 & 3,71 & 3,22 \\
\hline & $>6750 \mathrm{kn}$ & 12,22 & 4,75 & 2,88 & 4,59 & 3,32 & 3,81 & 3,50 \\
\hline \multirow{2}{*}{ Zaposlenost } & $\mathrm{Ne}$ & 10,66 & 4,23 & 2,83 & 3,60 & 2,76 & 3,77 & 2,97 \\
\hline & $\mathrm{Da}$ & 11,95 & 4,50 & 3,00 & 4,45 & 3,17 & 3,72 & 3,37 \\
\hline \multirow{4}{*}{$\begin{array}{l}\text { Broj stanov- } \\
\text { nika }\end{array}$} & $<2000$ & 11,04 & 4,38 & 2,95 & 3,70 & 2,82 & 3,69 & 3,08 \\
\hline & $<10000$ & 10,43 & 3,91 & 2,88 & 3,65 & 2,96 & 3,59 & 3,02 \\
\hline & $<100000$ & 10,93 & 4,15 & 2,95 & 3,84 & 2,86 & 3,64 & 3,27 \\
\hline & $>100000$ & 12,52 & 4,79 & 2,85 & 4,88 & 3,25 & 3,98 & 3,36 \\
\hline
\end{tabular}




\section{Postupak}

U ovom radu koristimo podatke dobivene u sklopu istraživačkog projekta »Mjerenje financijske pismenosti« koji su zajednički organizirali Hrvatska agencija za financijske usluge (HANFA) i Hrvatska narodne banka (HNB), u suradnji s Ministarstvom financija Republike Hrvatske. Istraživanje je provedeno kao jedna od aktivnosti u sklopu Akcijskog plana unaprjeđenja financijske pismenosti potrošača iz 2015. godine, a samo terensko anketiranje se provodilo od 21. 10. 2015. do 20. 11 . 2015. Samo istraživanje provela je agencija Ipsos d.o.o. koristeći OECD/INFE metodologiju tako da bi rezultati istraživanja mogli biti usporedivi s onima iz drugih država. U istraživanju je sudjelovalo 1049 sudionika koji su intervjuirani metodom licem u lice.

\section{REZULTATI}

Deskriptivna statistika, koeficijenti pouzdanosti i koeficijenti korelacija između varijabli korištenih u ovom istraživanju prikazani su u Tablici 3. Iz tablice je vidljivo da su povezanosti među subkomponentama OECD financijske pismenosti, prema Cohenovoj (1988.) konvenciji o veličinama efekata, niske, a u slučaju korelacije između znanja i stavova i neznačajne (primjerice, najveća korelacija među subkomponentama financijske pismenosti, između financijskog znanja i ponašanja, iznosi samo $r=0,21$ ). Stoga bi bilo korisno, osim kompozitne mjere financijske pismenosti, razmatrati i svaku komponentu zasebno. Povezanost samoprocijenjenog znanja s kompozitnom mjerom OECD financijske pismenosti, kao i njezinim subkomponentama, tek je nešto veća pa se, osim u slučaju stavova, može okarakterizirati kao umjerena. Primjerice, korelacija između samoprocijenjenog financijskog znanja i ponašanja iznosi $r=0,36$. Upravo umjerena korelacija samoprocijenjenog s objektivnim znanjem ukazuje na to da te dvije varijable nisu redundantne, odnosno da ih obje ima smisla mjeriti i istraživati.

Za razliku od prethodnih istraživanja na hrvatskom uzorku (Vehovec i sur., 2015.), u ovom istraživanju povezanosti spola i dobi sa svim mjerama znanja, stavova i ponašanja uglavnom su bile neznačajne, ili značajne ali vrlo niske. Ostale socio-demografske varijable ipak su se pokazale povezanijima s mjerama financijskih znanja i ponašanja. Općenito, obrazovanje, prihodi, radni status i veličina naselja, bili su pozitivno povezani s OECD mjerom financijske pismenosti, kao i s njezinim subkomponentama znanja i ponašanja, te s mjerama samoprocijenjenog financijskog znanja i financijskog planiranja. Ove korelacije uglavnom se kreću između niskih i umjerenih. Iznimkama od ovog trenda pokazali su se OECD financijski stavovi te financijska odgovornost čije su korelacije s navedenim socio-demografskim varijablama uglavnom bile neznačajne i vrlo niske. 


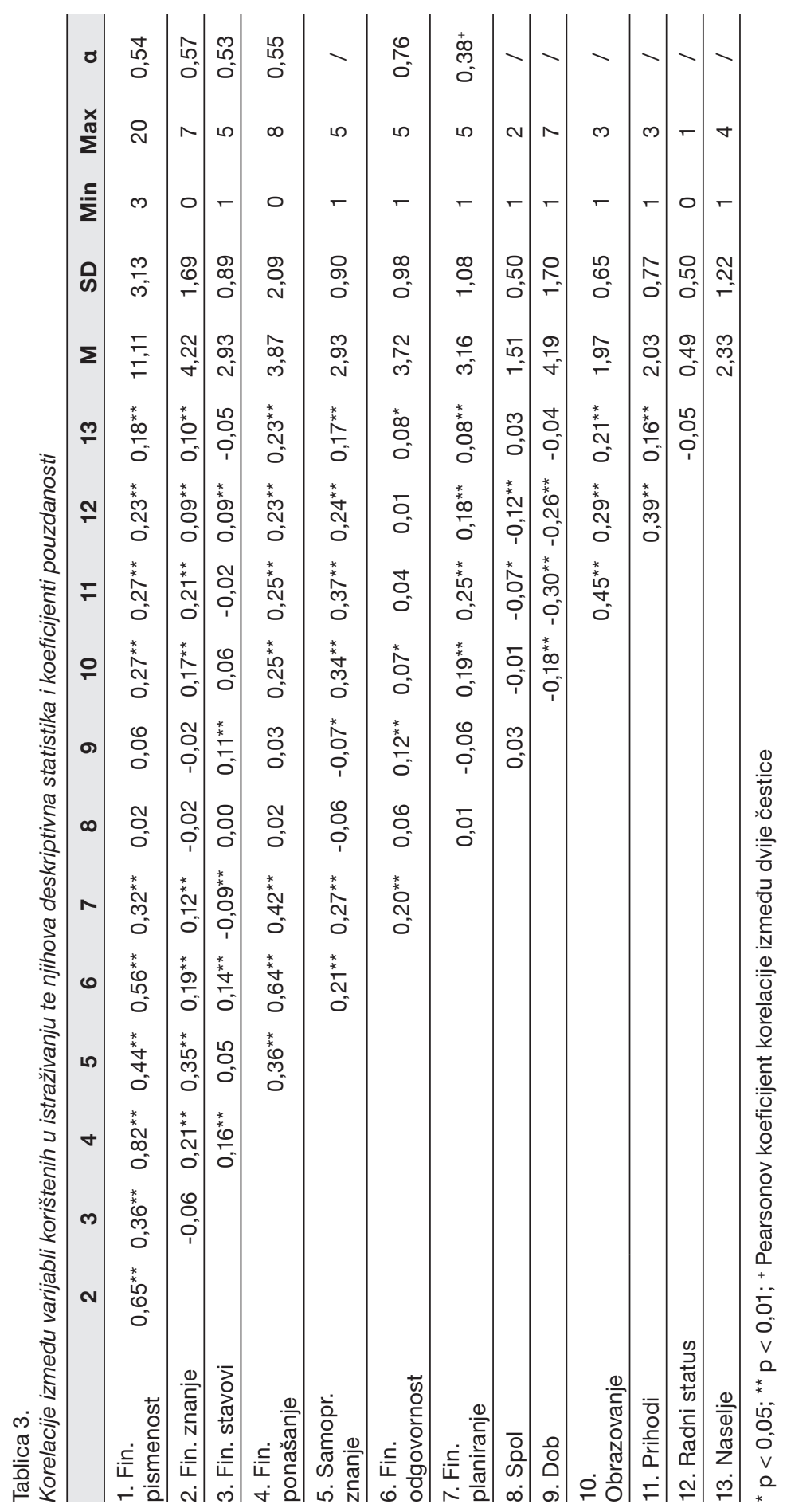


Kako bismo preciznije provjerili koliko su socio-demografske karakteristike uopće relevantne za financijsku pismenost i ostale mjere financijskog znanja i ponašanja, proveli smo sedam linearnih regresijskih analiza. Kao prediktore smo uvrstili socio-demografske varijable, pri čemu smo varijablu dobi, zbog zakrivljenog odnosa s financijskom pismenošću, rekodirali. Preciznije, zbog toga što su prethodna istraživanja, kao i naše trenutno, pokazala da su mlađi i stariji sudionici znatno manje financijski pismeni od onih srednjih godina, varijablu dobi prvo smo rekodirali u tri kategorije, mlađa dob (manje od 29 godina), srednja dob (između 29 i 59 godina) i starija dob (više od 59 godina). Zatim smo, u odnosu na referentnu grupu srednje dobi kreirali dvije dummy varijable, mlađa dob i starija dob, koje smo zatim koristili u analizama. Konačno, kriteriji su bili OECD financijska pismenost i njezine subkomponente znanja, stavova i ponašanja, kao i mjera samoprocjenjenog znanja te dvije dodatne mjere ponašanja, financijski odgovorno ponašanje i financijsko planiranje. Prije same provedbe analiza, provjerili smo zadovoljenost preduvjeta za provedbu regresijskih analiza. Svi ključni uvjeti poput linearnosti odnosa prediktora $\mathrm{i}$ kriterija, normalnosti distribucija reziduala, homoskedastičnosti i niske multikolinearnosti su ispunjeni (Field, 2013.). Rezultati navedenih regresijskih analiza prikazani su u Tablici 4.

Tablica 4.

Linearna regresijska analiza sa socio-demografskim varijablama kao prediktorima te financijskom pismenošću, financijskim znanjem, financijskim stavovima, samoprocijenjenim znanjem, financijskom odgovornošću $i$ financijskim planiranjem kao kriterijima.

\begin{tabular}{|c|c|c|c|c|c|c|c|}
\hline \multirow[t]{2}{*}{ Prediktori } & \multicolumn{7}{|c|}{ Kriteriji } \\
\hline & $\begin{array}{c}\text { Financij- } \\
\text { ska pisme- } \\
\text { nost }\end{array}$ & $\begin{array}{l}\text { Financij- } \\
\text { sko znanje }\end{array}$ & $\begin{array}{c}\text { Financijski } \\
\text { stavovi }\end{array}$ & $\begin{array}{l}\text { Financij- } \\
\text { sko pona- } \\
\text { šanje }\end{array}$ & $\begin{array}{c}\text { Samopro- } \\
\text { cjena zna- } \\
\text { nja }\end{array}$ & $\begin{array}{c}\text { Financij- } \\
\text { ska odgo- } \\
\text { vornost }\end{array}$ & $\begin{array}{l}\text { Financij- } \\
\text { sko plani- } \\
\text { ranje }\end{array}$ \\
\hline Spol & 0,03 & $-0,01$ & 0,00 & 0,03 & $-0,03$ & 0,05 & 0,03 \\
\hline Mlađi & $-0,13^{\star *}$ & $-0,08^{*}$ & $-0,09^{*}$ & $-0,07^{*}$ & $-0,13^{\star \star}$ & $-0,07^{\star}$ & 0,02 \\
\hline Stariji & 0,04 & $-0,05$ & 0,04 & 0,07 & $-0,05$ & 0,03 & 0,04 \\
\hline Obrazovanje & $0,14^{\star \star}$ & $0,08^{*}$ & $0,08^{*}$ & $0,11^{\star *}$ & $0,20^{\star \star}$ & 0,04 & 0,07 \\
\hline Prihodi & $0,16^{\star \star}$ & $0,16^{\star \star}$ & $-0,07$ & $0,14^{\star *}$ & $0,23^{\star *}$ & 0,03 & $0,19^{* *}$ \\
\hline Radni status & $0,12^{\star \star}$ & $-0,04$ & $0,09^{*}$ & $0,15^{\star \star}$ & 0,07 & $-0,03$ & $0,11^{\star *}$ \\
\hline Naselje & $0,16^{\star \star}$ & $0,08^{*}$ & $-0,06$ & $0,21^{\star \star}$ & $0,10^{\star \star}$ & $0,10^{\star \star}$ & $0,07^{*}$ \\
\hline $\mathrm{R}$ & 0,38 & 0,25 & 0,17 & 0,38 & 0,45 & 0,16 & 0,29 \\
\hline $\mathrm{R}^{2}$ & 0,15 & 0,06 & 0,03 & 0,14 & 0,21 & 0,02 & 0,09 \\
\hline Korigirani $\mathrm{R}^{2}$ & 0,14 & 0,05 & 0,02 & 0,14 & 0,20 & 0,02 & 0,08 \\
\hline$F(d f)$ & $\begin{array}{c}21,61 \\
(7,885)^{\star \star}\end{array}$ & $\begin{array}{c}8,62 \\
(7,936)^{\star \star}\end{array}$ & $\begin{array}{c}3,65 \\
(7,885)^{\star \star}\end{array}$ & $\begin{array}{c}22,01 \\
(7,936)^{\star \star}\end{array}$ & $\begin{array}{c}34,05 \\
(7,917)^{\star \star}\end{array}$ & $\begin{array}{c}3,13 \\
(7,885)^{\star \star}\end{array}$ & $\begin{array}{c}12,04 \\
(7,902)^{\star \star}\end{array}$ \\
\hline
\end{tabular}

${ }^{*} \mathrm{p}<0,05 ;{ }^{* *} \mathrm{p}<0,01$ 
Iz Tablice 4. vidljivo je da su svi regresijski modeli značajni, odnosno da socio-demografske varijable objašnjavaju značajan dio varijance svih ispitivanih kriterija. Međutim, iako su regresijski modeli značajni, postotak varijance u zavisnim varijablama koji objašnjavaju uglavnom je nizak do umjeren. Drugim riječima, čini se da socio-demografske karakteristike pojedinca nisu toliko značajne i relevantne za njegovu/ njezinu razinu financijske pismenosti. Naime, najveći postotak varijance koji su socio-demografske varijable objasnile u ovom istraživanju je u samoprocijenjenom znanju, ali i tu je objašnjeno relativno skromnih $20 \%$. S druge strane, promatrani prediktori objasnili su samo $14 \%$ varijance u mjeri OECD financijske pismenosti. Gledajući pojedinačne subkomponente OECD financijske pismenosti, najviše varijance objašnjeno je u financijskom ponašanju (14\%), zatim u financijskom znanju (5\%), dok je najmanje objašnjeno u financijskim stavovima (samo 2\%). Dodatne mjere financijskih ponašanja također nisu adekvatno zahvaćene socio-demografskim karakteristikama: u financijskom planiranju objašnjeno je $9 \%$ varijance, a u financijski odgovornom ponašanju samo $2 \%$.

Promatrajući pojedinačne prediktore, čini se da su se sudionici značajno razlikovali u financijskoj pismenosti, kao i OECD komponenti financijskog ponašanja, u ovisnosti o dobi, obrazovanju, prihodima, radnom statusu i veličini naselja u kojem žive. Preciznije, mlađi sudionici, u odnosu na one srednje dobi, iskazuju značajno nižu razinu financijske pismenosti i neadekvatnija financijska ponašanja. S druge strane, obrazovaniji i zaposleni sudionici, oni s višim primanjima, kao i oni koji žive u većim naseljima, financijski su pismeniji i iskazuju adekvatnija ponašanja od manje obrazovanih, nezaposlenih, onih s nižim primanjima i iz manjih sredina. Slična situacija je i sa subkomponentom OECD financijskog znanja, s tom razlikom što se sudionici nisu razlikovali u financijskom znanju u ovisnosti o radnom statusu. Što se tiče komponenti OECD financijske pismenosti, čini se da su financijski stavovi najmanje osjetljivi na socio-demografske karakteristike. Sudionici su se u svojim stavovima razlikovali samo u ovisnosti o dobi, obrazovanju i radnom statusu, na način da su mlađi u odnosu na one srednje dobi imali lošije financijske stavove, dok su obrazovaniji i zaposleni imali bolje stavove u odnosu na manje obrazovane i nezaposlene. Razlika prema spolu, prihodima i veličini naselja nije bilo.

Što se tiče dodatnih varijabli koje smo ovdje istraživali, a koje nisu u originalnoj OECD-ovoj definiciji financijske pismenosti, čini se da su socio-demografske varijable najrelevantnije za samoprocijenjeno financijsko znanje. Naime, dob, obrazovanje, prihodi i veličina naselja pokazali su se značajnim prediktorima samoprocijenjenog znanja. Točnije, mlađi sudionici procjenjivali su da imaju manje financijskog znanja od sudionika srednje dobi, dok su se oni obrazovaniji, viših prihoda i iz većih naselja procjenjivali upućenijima od manje obrazovanih, s nižim prihodima i iz manjih mjesta. Što se tiče dodatnih mjera financijskih ponašanja, samo dvije socio-demografske varijable pokazale su se relevantnima za financijski odgovorno ponašanje: čini se da se mlađi sudionici ponašaju na financijski neodgovorniji način od onih srednje dobi, dok su oni koji žive u većim naseljima nešto odgovorniji od onih iz manjih naselja. Konačno, izraženije financijsko planiranje iskazivali su zaposleni sudionici s većim primanjima, kao i oni koji žive u naseljenijim mjestima, u odnosu na nezaposlene, one s nižim primanjima te one iz manje naseljenih mjesta. Deskriptivna statistika svih kriterijskih varijabli u odnosu na socio-demografske prikazana je u Tablici 2.

Osim ukupno objašnjena varijance u kriterijima, u ovom istraživanju htjeli smo 
provjeriti i koliko svaki od ispitivanih prediktora pojedinačno doprinosi objašnjenu varijance u svakom od kriterija. Dugim riječima, htjeli smo provjeriti relevantnost svake od mjerenih socio-demografskih varijabli za pojedini kriterij financijske pismenosti. Kako bismo to doznali, proveli smo tzv. analizu dominacije (Azen i Budescu, 2003.; Budescu, 1993.; LeBreton i Tonidandel, 2008.). Naime, beta ponderi su dobar pokazatelj važnosti određenog prediktora za neki kriterij u setu prediktora u situaciji kad nema povezanosti među prediktorima, odnosno u potpunom odsustvu multikolinearnosti. Međutim, kad postoji povezanost među prediktorima, beta ponderi više nisu dobar pokazatelj važnosti prediktora, odnosno veći beta ponder ne znači nužno da taj prediktor objašnjava veći dio varijance $\mathrm{u}$ kriteriju od nekog drugog prediktora u modelu. Bez obzira što u ovom istraživanju nemamo visokih korelacija među prediktorima pa tako ni problema s multikolinearnošću, neke veličine korelacija ipak se mogu klasificirati kao umjerene (Cohen, 1988.). Primjerice, korelacije prihoda s dobi, obrazovanjem i radnim statusom su sve umjerene visine, što bi moglo iskriviti značenje beta pondera u regresiji. S druge strane, analiza dominacije omogućuje uspoređivanje prediktora prema relevantnosti i u situacijama povezanosti među prediktorima. Koeficijent generalne dominacije računa se tako da se uprosječi dodatan doprinos odre- đenog prediktora u svim mogućim pod-setovima regresijskih modela. Primjerice, ukoliko bismo htjeli izračunati koeficijent generalne dominacije prediktora $\mathrm{X} 1 \mathrm{u}$ setu od ukupno tri prediktora, prvo bismo izračunali doprinos prediktora $\mathrm{X} 1\left(\Delta \mathrm{R}^{2}\right) \mathrm{u}$ svim mogućim situacijama: kad u modelu nema dodatnih prediktora osim X1, uz dodatni prediktor X2, uz dodatni prediktor X3, te uz oba dodatna prediktora. U posljednjem koraku uprosječili bismo sve dobivene $\Delta R^{2}$ i na taj način dobili koeficijent generalne dominacije (LeBreton i Tonidandel, 2008.). Koeficijent dominacije ima nekoliko korisnih i povoljnijih karakteristika u odnosu na beta pondere. Prvo, predstavlja točniju mjeru relevantnosti prediktora za pojedini kriterij u situacijama kada su prediktori u međusobnim korelacijama. Drugo, koeficijent generalne dominacije intuitivan je i predstavlja postotak varijance u kriteriju koji je objašnjen pojedinim prediktorom. Konačno, vezano uz prethodnu karakteristiku, zbroj koeficijenata dominacije svakog pojedinog prediktora u modelu jednak je $R^{2}$, odnosno ukupnoj varijanci objašnjenoj tim modelom. Koeficijente dominacije u ovom istraživanju izračunali smo pomoću R paketa »yhat« (Nimon, Oswald i Roberts, 2013.). U Tablici 5. prikazani su prediktori poredani po važnosti za pojedini kriterij, zajedno s koeficijentima dominacije svakog pojedinog prediktora. 
Tablica 5.

Koeficijenti generalne dominacije prediktora u svakom od ispitivanih kriterija

\begin{tabular}{ccccccc}
\hline $\begin{array}{c}\text { Financijska } \\
\text { pismenost }\end{array}$ & $\begin{array}{c}\text { Financijsko } \\
\text { znanje }\end{array}$ & $\begin{array}{c}\text { Financijski } \\
\text { stavovi }\end{array}$ & $\begin{array}{c}\text { Financijsko } \\
\text { ponašanje }\end{array}$ & $\begin{array}{c}\text { Samoprocje- } \\
\text { na znanja }\end{array}$ & $\begin{array}{c}\text { Financijska } \\
\text { odgovornost }\end{array}$ & $\begin{array}{c}\text { Financijsko } \\
\text { planiranje }\end{array}$ \\
\hline $\begin{array}{c}\text { Prihodi } \\
(0,040)^{*}\end{array}$ & $\begin{array}{c}\text { Prihodi } \\
(0,028)\end{array}$ & $\begin{array}{c}\text { Mlađi } \\
(0,011)\end{array}$ & $\begin{array}{c}\text { Naselje } \\
(0,048)\end{array}$ & $\begin{array}{c}\text { Prihodi } \\
(0,076)\end{array}$ & $\begin{array}{c}\text { Naselje } \\
(0,010)\end{array}$ & $\begin{array}{c}\text { Prihodi } \\
(0,043)\end{array}$ \\
\hline $\begin{array}{c}\text { Obrazovanje } \\
(0,036)\end{array}$ & $\begin{array}{c}\text { Obrazovanje } \\
(0,015)\end{array}$ & $\begin{array}{c}\text { Radni status } \\
(0,007)\end{array}$ & $\begin{array}{c}\text { Prihodi } \\
(0,034)\end{array}$ & $\begin{array}{c}\text { Obrazovanje } \\
(0,065)\end{array}$ & $\begin{array}{c}\text { Mlađi } \\
(0,005)\end{array}$ & $\begin{array}{c}\text { Obrazovanje } \\
(0,016)\end{array}$ \\
\hline Naselje & Naselje & Obrazovanje & Obrazovanje & Radni status & Spol & Radni status \\
$(0,030)$ & $(0,009)$ & $(0,004)$ & $(0,027)$ & $(0,025)$ & $(0,003)$ & $(0,016)$ \\
\hline Radni status & Mlađi & Naselje & Radni status & Naselje & Obrazovanje & Naselje \\
$(0,020)$ & $(0,004)$ & $(0,004)$ & $(0,022)$ & $(0,016)$ & $(0,003)$ & $(0,007)$ \\
\hline Mlađi & Stariji & Prihodi & Mlađi & Mlađi & Stariji & Stariji \\
$(0,017)$ & $(0,003)$ & $(0,002)$ & $(0,006)$ & $(0,013)$ & $(0,002)$ & $(0,004)$ \\
\hline Stariji & Radni status & Stariji & Stariji & Stariji & Prihodi & Spol \\
$(0,003)$ & $(0,002)$ & $(0,001)$ & $(0,003)$ & $(0,012)$ & $(0,001)$ & $(0,001)$ \\
\hline Spol & Spol & Spol & Spol & Spol & Radni status & Mlađi \\
$(0,001)$ & $(0,000)$ & $(0,000)$ & $(0,001)$ & $(0,001)$ & $(0,001)$ & $(0,000)$ \\
\hline
\end{tabular}

* U zagradama su prikazani koeficijenti dominacije za svaki prediktor, odnosno procjena objašnjene varijance u kriteriju koju taj prediktor samostalno objašnjava. Zbroj koeficijenata dominacije svih prediktora odgovara ukupno modelom objašnjenoj varijanci $R^{2}$. Prediktori su poredani od najvažnijeg prema najmanje važnom za svaki kriterij.

Iz Tablice 5. vidljivo je da, iako važnost prediktora značajno varira od kriterija do kriterija, nekakve generalne obrasce je moguće identificirati. Primjerice, prihodi kućanstva među najvažnijima su od promatranih prediktora za većinu kriterija. Preciznije, prihodi su objašnjavali najveći postotak varijance od svih ostalih prediktora u OECD mjeri financijske pismenosti (4\%), subkomponenti financijskog znanja $(2,8 \%)$, samoprocijenjenom znanju $(7,6 \%)$ te financijskom planiranju (4,3\%). Također, bili su drugi najznačajniji prediktor u objašnjenju varijance OECD subkomponente financijskog ponašanja $(3,4 \%)$. Veličina naselja u kojem sudionik živi najvažniji je prediktor financijskog ponašanja u kojem objašnjava $4,8 \%$ varijance, te financijski odgovornog ponašanja s $1 \%$ objašnjena varijance. Iako nije najvažniji prediktor niti za jedan od promatranih kriterija, razina obrazovanja ipak je relativno relevantan prediktor jer je u čak četiri slučaja drugi prediktor po važ- nosti u modelu. U financijskoj pismenosti objašnjava 3,6\% varijance, u objektivnom znanju 1,5\%, u samoprocijenjenom znanju $6,5 \%$ varijance te u financijskom planiranju 1,6\% varijance. S druge strane, čini se da je spol sudionika najmanje relevantna varijabla za financijsku pismenost. Naime, spol je u čak pet promatranih kriterija bila najmanje važan prediktor, a čak i u slučajevima u kojima nije bila najmanje važan prediktor, objašnjavala je vrlo nizak postotak varijance (najviše varijance objašnjene spolom ispitanika je u financijskoj odgovornosti, samo $0,3 \%$ ).

\section{RASPRAVA}

Provedeno istraživanje imalo je za cilj provjeriti povezanosti određenih socio-demografskih karakteristika s mjerama financijske pismenosti i njezinih komponenata, odnosno konceptualno replicirati rezultate dobivene u istraživanju Vehovec i sur. 
(2015.). Dodatno, za cilj smo imali i provjeriti važnost socio-demografskih karakteristika za varijable relevantne za financijsku pismenost koje nisu prije provjeravane $\mathrm{u}$ hrvatskom kontekstu: samoprocijenjeno financijsko znanje, te dodatne varijable financijskih ponašanja, financijski odgovorno ponašanje i financijsko planiranje. Konačno, cilj nam je bio i empirijski utvrditi koliko su uopće socio-demografske varijable relevantne za financijsku pismenost, odnosno usporediti njihovu važnost za različite elemente financijske pismenosti. Informacija o tome koliko toga ostaje neobjašnjeno socio-demografskim varijablama govori nam o tome ima li smisla tražiti i identificirati neke dodatne, potencijalno relevantnije faktore, na koje bi se, primjerice, mogle usredotočiti različite obrazovne intervencije. Znanje o relevantnosti pojedinih socio-demografskih karakteristika za pojedinčevu financijsku pismenost također govori prema kojim skupinama ima smisla usmjeriti eventualne intervencije, ali i može ukazati na potencijalne limite intervencija usmjerenih povećanju financijske pismenosti, ukoliko ona u velikoj mjeri ovisi o relativno stabilnim i teško promjenjivim karakteristikama (primjerice, mjestu u kojem pojedinac živi, radnom statusu ili prihodu).

Rezultati ovog istraživanja ukazuju na to da su socio-demografske varijable, gledajući sveukupno, relativno loši prediktori različitih financijskih ishoda. Čini se da su najrelevantnije za varijablu samoprocijenjenog financijskog znanja, dok su skoro pa potpuno irelevantne za financijske stavove $\mathrm{i}$ financijski odgovorno ponašanje. Međutim, iako skroman, njihov doprinos objašnjenju financijske pismenosti, znanja, stavova i ponašanja može ukazivati na moguće limite u uspješnosti eventualnih obrazovnih intervencija usmjerenih povećanju financijske pismenosti i kvalitete ponašanja. Naime, ukoliko su financijski ishodi zaista pod određenim utjecajem situacijskih, teško promjenjivih faktora poput mjesta stanova- nja, obrazovanja, radnog statusa ili prihoda, tada će bilo koja intervencija usmjerena na faktore na koje je lakše utjecati nužno imati ograničen uspjeh. Promatrajući koeficijente dominacije za, primjerice, financijska ponašanja, vidimo da su upravo navedena četiri faktora najrelevantnija od promatranih, objašnjavajući ukupno čak $13 \%$ varijance u financijskoj pismenosti i financijskim ponašanjima. Kad se uzme u obzir da, zbog nesavršenosti i niskih pouzdanosti mjera financijske pismenosti, postoji teoretska gornja granica u varijanci koju je uopće moguće objasniti nekim setom prediktora, čak i kad bi se pronašli svi relevantni faktori koji utječu na nečija financijska ponašanja, prostor za intervenciju je značajno sužen. Stoviše, osim ovih koje smo ispitivali u trenutnom istraživanju, vjerojatno postoji još značajnih situacijskih faktora koji bi dodatno suzili mogućnosti utjecaja na financijsku pismenost i ponašanja. Primjerice, utjecaj vršnjaka i socijalne mreže mogle bi biti jedan od takvih faktora. Smatramo da time zadatak identificiranja značajnih i relevantnih psiholoških faktora koji bi mogli imati utjecaj na financijske ishode, a istodobno biti promjenjivi i pogodni za ciljanje potencijalnim intervencijama, postaje vrlo bitan.

Trenutni rezultati donekle se razlikuju od rezultata istraživanja Vehovec i sur. (2015.), a ujedno ga i nadopunjavaju novim spoznajama. Konkretno, u istraživanju navedenih autora, sudionici su se značajno razlikovali u svojoj financijskoj pismenosti i financijskom znanju gotovo u svim promatranim socio-demografskim faktorima. S druge strane, u našem istraživanju nisu se svi socio-demografski čimbenici pokazali važnima za sve testirane kriterije. Konkretno, sudionici se nisu značajno razlikovali u financijskoj pismenosti po spolu, dok za financijsko znanje, uz spol, nije bila značajna ni varijabla radnog statusa. S druge strane, što se tiče financijskih stavova i ponašanja, u ovom se istraživanju više faktora pokazalo značajnima za navedene ishode nego 
što je to bio slučaj u istraživanju Vehovec i sur. (2015.). Primjerice, u istraživanju navedenih autora, niti jedna socio-demografska varijabla nije se pokazala značajnom u razlikovanju sudionika s obzirom na njihove financijske stavove. Za razliku od toga, u našem istraživanju sudionici su se značajno razlikovali u svojim stavovima s obzirom na dob i radni status. Također, za razliku od prethodnog istraživanja gdje su se obrazovanje i prihodi pokazali značajnima za pojedinčeva financijska ponašanja, u našem istraživanju značajni prediktori OECD subkomponente financijskih ponašanja bili su prihodi, radni status i veličina naselja u kojem pojedinac živi, dok se obrazovanje nije pokazalo značajnim prediktorom. Međutim, najznačajnija razlika između dvaju istraživanja je relevantnost spola za financijsku pismenost. Dok su se u prvom istraživanju sudionici značajno razlikovali u financijskoj pismenosti i znanju po spolu, u trenutnom istraživanju spol nije bio značajan prediktor niti jednog od promatranih ishoda. Potpuna irelevantnost spola za financijsku pismenost je iznenađujuća s obzirom na prethodna istraživanja prema kojima su spolne razlike među najkonzistentnijim nalazima istraživanja financijske pismenosti. Prema nekim autorima (npr. Bucher-Koenen i sur., 2016.), muškarci iskazuju znatno veće samopouzdanje od žena u vlastito financijsko znanje, a upravo to veće samopouzdanje i entuzijazam vezan uz financijska pitanja mogu rezultirati većim financijskim iskustvom i pismenošću muškaraca u odnosu na žene. U istraživanjima se samopouzdanje u vlastito znanje često reflektira u sklonosti davanja »ne znam« odgovora (Xia, Wang i Li, 2014.), pa tako žene češće u odgovorima biraju opciju »ne znam« od muškaraca. Kako bi provjerili postoje li spolne razlike u samopouzdanju vezanom uz vlastito znanje, odnosno u frekvenciji biranja »ne znam« odgovora, analizirali smo odgovore na četiri pitanja financijskog znanja. Na našem uzorku nije bilo spolnih razlika u čestini »ne znam « odgovora $\left(\chi^{2}(3)\right.$ $=0,02, \mathrm{p}>0,05)$. Stoga je moguće da nepostojanje spolnih razlika u samopouzdanju u vlastito znanje može objasniti nepostojanje razlika u financijskoj pismenosti na našem uzorku, ali to je spekulacija koju u budućnosti treba dodatno istražiti.

Gledajući sveukupno rezultate, može se reći da je naše istraživanje samo djelomično repliciralo rezultate istraživanja Vehovec i sur. (2015.), gdje su najsličniji rezultati dobiveni za ukupnu mjeru financijske pismenosti i mjeru financijskog znanja, dok su se razlike donekle pojavile za mjere financijskih stavova i ponašanja. Navedene nepodudarnosti u rezultatima najvjerojatnije se mogu pripisati nekim od sljedećih razloga. Prvo, uzorci u dvama istraživanjima razlikovali su u nekim potencijalno značajnim aspektima. Primjerice, u odnosu na trenutno istraživanje, u istraživanju Vehovec i sur. (2015.) bilo je manje sudionika sa završenom samo osnovnom školom $(22,8 \%$ prema $8,2 \%$ ), a više onih visoko obrazovanih (19,9\% prema $28,1 \%)$. Također, u trenutnom istraživanju bilo je oko $10 \%$ sudionika starijih od 70 godina, dok je maksimalna dob $\mathrm{u}$ prethodnom istraživanju bila 65 godina. Osim u uzorku, dva istraživanja bitno se razlikuju i u metodi obrade podataka. Naime, $u$ trenutnom istraživanju, za razliku od prethodnog, koristili smo se multivarijatnim statističkim postupcima koji uzimaju u obzir međuodnose varijabli u modelu. Primjerice, u prethodnom istraživanju sudionici su se razlikovali u financijskoj pismenosti i po dobi i po obrazovanju. Za ilustraciju, možemo pretpostaviti da su stariji pojedinci ujedno i obrazovaniji, pa je moguće da su se dobne razlike pojavile samo kao posljedica razlika u obrazovanju. Međutim, univarijatni postupci nam ne mogu reći koliki je stvarni doprinos svake od varijabli objašnjenju financijske pismenosti. S druge strane, korištenjem multivarijatnih metoda, dobili smo jedinstvene, na neki način »či- 
šće «, doprinose svakog pojedinog prediktora. Također, gledajući ukupan doprinos svih socio-demografskih varijabli, ovakav postupak omogućio nam je i da donesemo zaključak o tome da ove varijable, iako značajne, vjerojatno nisu najrelevantniji faktori u objašnjenju financijske pismenosti. U tom smislu, moglo bi se reći da je ovo istraživanje na neki način repliciralo prethodno istraživanje Vehovec i sur. (2015.). Naime, iako autori eksplicitno ne donose takav zaključak, razlike u komponentama financijske pismenosti u ovisnosti o većini socio-demografskih varijabli u prethodnom istraživanju bile su, iako značajne, relativno skromne, pa i to navodi na zaključak o ograničenoj relevantnosti socio-demografskih varijabli za financijsku pismenost.

Jedan od razloga zbog kojeg su socio-demografske varijable slabi prediktori financijske pismenosti vjerojatno je psihometrijske naravi, što se ogleda u relativno lošim psihometrijskim karakteristikama poput niskih pouzdanosti (Tablica 3.). Međutim, vrlo veliki postotak varijance koji je ostao neobjašnjen socio-demografskim varijablama (primjerice, 85\% neobjašnjena varijance u financijskoj pismenosti i čak 97\% u financijskim stavovima) ukazuje na to da postoje druge relevantne varijable koje značajno objašnjavaju financijsku pismenost a nisu uključene u trenutni model. $\mathrm{U}$ literaturi postoje istraživanja koja su u modele predviđanja financijskih ponašanja, što je jedna od glavnih komponenti financijske pismenosti prema OECD definiciji, uključivali i neke druge, uglavnom psihološke, varijable. Primjerice, numerička inteligencija, sklonost riziku, samopouzdanje u odluke i planiranje (Fernandes, Lynch i Netemeyer, 2014.), kao i različite kognitivne pristranosti i samokontrola (Huston, 2010.), mogu značajno utjecati na financijske ishode. Također, pokazalo se da različiti kognitivni stilovi poput potrebe za kognitivnim zatvaranjem ili orijentacije na budućnost
(Jacobs-Lawson i Hershey, 2005.), kao i samoaktualizacijske vrijednosti (Shim, Xiao, Barber i Lyons, 2009.), igraju ulogu u pojedinčevim financijskim ponašanjima $\mathrm{i}$ ishodima. Osim toga, percipirana osobna kontrola nad ponašanjem kao i stavovi igraju važnu ulogu u odgovornom financijskom ponašanju (Lučić, Barbić i Chen, 2019.), pa ne čudi da aktivnosti usmjerene na mijenjanje tih determinanti mogu uzrokovati znatne promjene u financijskim ponašanjima pojedinaca. Primjerice, Škalamera-Alilović, Dimitrić i Kupinić-Guščić (2018.) su pokazale da novčana sredstva koja banke ulože u promotivne i marketinške aktivnosti izravno utječu na povećanje kreditnih zaduživanja kućanstava. Konačno, određene dimenzije ličnosti, poput savjesnosti (Brown i Taylor, 2014.; Hershey i Mowen, 2000.; Xu i sur., 2015.), ali i ekstraverzije i neuroticizma (Yang, Lester i Spinella, 2009.), također su se pokazale značajnima za financijska ponašanja. Dakle, buduća istraživanja trebala bi u modele objašnjenja financijske pismenosti, osim socio-demografskih varijabli, uključiti i druge, potencijalno relevantne psihološke varijable. Dodana vrijednost ovakvih istraživanja bila bi i u tome što su određeni psihološki konstrukti, poput stavova ili uvjerenja, jednom kad se utvrdi njihova relevantnost za financijske ishode, vjerojatno promjenjiviji i prikladniji za »ciljanje« potencijalnim intervencijama nego što su to relativno stabilne i nepromjenjive socio-demografske karakteristike. Stoga smatramo da bi se buduća istraživanja financijske pismenosti trebala orijentirati upravo u tom smjeru.

\section{ZAKLJUČAK}

Ovo istraživanje pokazalo je da socio-demografske varijable, iako značajne, ipak nisu toliko relevantne odrednice financijske pismenosti. Gledajući zasebno elemente financijske pismenosti prema OECD definiciji, socio-demografske va- 
rijable pokazale su se najprediktivnijima za ukupnu mjeru financijske pismenosti te za mjeru financijskih ponašanja, dok su se najmanje relevantnima pokazale za financijske stavove. Ovakvi rezultati ukazuju na mogućnost da postoje dodatne relevantne, a trenutnim modelom neidentificirane, varijable koje bi se u budućim istraživanjima financijske pismenosti svakako trebale uzeti u obzir. Iako se rezultati ovog istraživanja djelomično preklapaju s onima Vehovec i sur. (2015.), najznačajnija razlika je u potpunoj odsutnosti spolnih razlika u financijskoj pismenosti u ovom istraživanju. Jedan od potencijalnih razloga je nepostojanje spolnih razlika u samopouzdanju u vlastito znanje, no tu će pretpostavku također trebati provjeriti budućim istraživanjima. Konačno, gledajući relevantnost pojedinačnih prediktora u modelu za svaki od kriterija, čini se da su često upravo oni faktori koji su najstabilniji i najmanje podložni promjenama, poput mjesta stanovanja, obrazovanja ili prihoda, ujedno i najznačajniji za aspekte financijske pismenosti. Ovaj nalaz može ukazivati na teoretska ograničenja dosega eventualnih obrazovnih ili bihevioralnih intervencija usmjerenih povećavanju financijske pismenosti pojedinaca.

\section{LITERATURA}

Aertsens, J., Mondelaers, K., Verbeke, W., Buysse, J., \& Van Huylenbroeck, G. (2011). The influence of subjective and objective knowledge on attitude, motivations and consumption of organic food. British Food Journal, 113(11), 1353-1378. https:// doi.org/10.1108/00070701111179988

Alsemgeest, L. (2015). Arguments for and against financial literacy education: where to go from here?. International Journal of Consumer Studies, 39(2), 155-161. https://doi.org/10.1111/ ijcs. 12163

Atkinson, A., \& Messy, F. A. (2012). Measuring financial literacy: Results of the OECD. Paris: OECD Publishing.

Atkinson, A., Monticone, C., \& Messy, F. A. (2016). OECD/INFE International Survey of Adult Financial Literacy Competencies. Technical Report. Paris: OECD.
Azen, R., \& Budescu, D. V. (2003). The dominance analysis approach for comparing predictors in multiple regression. Psychological methods, 8(2), 129-148. https://doi.org/10.1037/1082989X.8.2.129

Brown, S., \& Taylor, K. (2014). Household finances and the 'Big Five'personality traits. Journal of Economic Psychology, 45, 197-212. https://doi. org/10.1016/j.joep.2014.10.006

Bahovec, V., Barbić, D., \& Palić, I. (2017). The regression analysis of individual financial performance: Evidence from Croatia. Business Systems Research Journal: International Journal of the Society for Advancing Business \& Information Technology (BIT), 8(2), 1-13.https:// doi.org/10.1515/bsrj-2017-0012

Barbić, D., Lučić, A., \& Chen, J. M. (2019). Measuring responsible financial consumption behaviour. International Journal of Consumer Studies, 43(1), 102-112. https://doi.org/10.1111/ijcs.12489

Barbić, D., Palić, I., \& Bahovec, V. (2016). Logistic regression analysis of financial literacy implications for retirement planning in Croatia. Croatian Operational Research Review, 7(2), 319-331. https://doi.org/10.17535/crorr.2016.0022

Bucher-Koenen, T., Lusardi, A., Alessie, R., \& Rooij, M. (2016). How financially literate are women? An overview and new insights. Journal of Consumer Affairs, 51(2), 255-283. https://doi. org/10.1111/joca.12121

Budescu, D. V. (1993). Dominance analysis: A new approach to the problem of relative importance of predictors in multiple regression. Psychological Bulletin, 114(3), 542-551. https://doi. org/10.1037/0033-2909.114.3.542

Bujan, I., Cerović, L., \& Samaržija, N. D. (2016). Socio demographic determinants of financial literacy of the citizens of the Republic of Croatia. Ekonomski pregled, 67(3), 206-226. https:// hrcak.srce.hr/162253

Chen, H., \& Volpe, R. P. (2002). Gender differences in personal financial literacy among college students. Financial Services Review, 11(3), 289.

Cohen, J. (1988). Statistical power analysis for the behavioral sciences. Hilsdale, NJ: Lawrence Earlbaum Associates.

Cvrlje, D. (2014). Linking the concept of financial literacy with the successfulness in managing personal finances (doctoral dissertation). Ekonomski fakultet, Sveučilište u Zagrebu.

Fernandes, D., Lynch Jr, J. G., \& Netemeyer, R. G. (2014). Financial literacy, financial education, and downstream financial behaviors. Man- 
agement Science, 60(8), 1861-1883. https://doi. org/10.1287/mnsc.2013.1849

Field, A. (2013). Discovering statistics using IBM SPSS statistics. Thousand Oaks, CA: SAGE.

Habschick, M., Seidl, B., \& Evers, J. (2007). Survey of financial literacy schemes in the EU27. VT Markt/2006/26H-Final Report, Hamburg.

Hastings, J. S., Madrian, B. C., \& Skimmyhorn, W. L. (2013). Financial literacy, financial education, and economic outcomes. Annual Review of Economics, 5(1), 347-373. https://doi.org/10.1146/ annurev-economics-082312-125807

Hershey, D. A., \& Mowen, J. C. (2000). Psychological determinants of financial preparedness for retirement. The Gerontologist, 40(6), 687-697. https://doi.org/10.1093/geront/40.6.687

Hung, A., Parker, A. M., \& Yoong, J. (2009). Defining and measuring financial literacy. RAND Working Paper 708. Available at https://www.rand.org/ pubs/working_papers/WR708.html

Huston, S. J. (2010). Measuring financial literacy. Journal of Consumer Affairs, 44(2), 296-316. https://doi.org/10.1111/j.1745-6606.2010.01170.x

Ipsos Public Affairs. (2015). Mjerenje financijske pismenosti i financijske uključenosti u Hrvatskoj. Dostupno na https:/www.hanfa.hr/getfile.ashx $/$ ?fileId=43343

Jacobs-Lawson, J. M., \& Hershey, D. A. (2005). Influence of future time perspective, financial knowledge, and financial risk tolerance on retirement saving behaviors. Financial Services Review, 14(4), 331.

Kaiser, H. F. (1974). An index of factorial simplicity. Psychometrics, 39(1), 31-36. https://doi. org/10.1007/BF02291575

LeBreton, J. M., \& Tonidandel, S. (2008). Multivariate relative importance: Extending relative weight analysis to multivariate criterion spaces. Journal of Applied Psychology, 93(2), 329-345. https://doi.org/10.1037/0021-9010.93.2.329

Lusardi, A., \& Mitchell, O. S. (2014). The economic importance of financial literacy: Theory and evidence. Journal of Economic Literature, 52(1), 5-44. https://doi.org/10.1257/jel.52.1.5

Nacionalni strateški okvir financijske pismenosti potrošača za razdoblje od 2015. do 2020. godine i Akcijski plan unaprjeđenja financijske pismenosti potrošača za 2015. godinu. Narodne novine, br. 11/2015.

Nimon, K., Oswald, F. L., \& Roberts, J. K. (2013). Yhat: Interpreting regression effects. $\mathrm{R}$ package version 2-0. Available at https://rdrr.io/cran/yhat/
Organisation for Economic Co-operation and Development. (2015). Toolkit for measuring financial literacy and financial inclusion. Available at http://www. oecd.org/daf/fin/financial-education/2015_OECD_ INFE_Toolkit_Measuring_Financial_Literacy.pdf

Pieniak, Z., Aertsens, J., \& Verbeke, W. (2010). Subjective and objective knowledge as determinants of organic vegetables consumption. Food Quality And Preference, 21(6), 581-588. https://doi. org/10.1016/j.foodqual.2010.03.004

Remund, D. L. (2010). Financial literacy explicated: The case for a clearer definition in an increasingly complex economy. Journal of Consumer Affairs, 44(2), 276-295. https://doi.org/10.1111/j.17456606.2010.01169.x

Shim, S., Xiao, J. J., Barber, B. L., \& Lyons, A. C. (2009). Pathways to life success: A conceptual model of financial well-being for young adults. Journal of Applied Developmental Psychology, 30(6), 708-723. https://doi.org/10.1016/j.appdev.2009.02.003

Svjetska banka. (2010). Hrvatska - Dijagnostički pregled zaštite potrošača i financijske pismenosti. Svezak II: Usporedba s dobrim praksama. Zagreb: Svjetska banka.

Škreblin Kirbiš, I., Tomić, I., \& Vehovec, M. (2011). Mirovinska pismenost i štednja za treću životnu dob. Revija za socijalnu politiku, 18(2), 127-148. https://doi.org/10.3935/rsp.v18i2.1004

Škreblin Kirbiš, I., Vehovec, M., \& Galić, Z. (2017). Relationship between financial satisfaction and financial literacy: Exploring gender differences. Društvena istraživanja, 26(2), 165-185. https:// doi.org/10.5559/di.26.2.02

Vehovec, M., Rajh, E., \& Škreblin Kirbiš, I. (2015). Financijska pismenost građana u Hrvatskoj. Privredna kretanja i ekonomska politika, 24 (1(136)), 5376. https://hrcak.srce.hr/140044

Willis, L. E. (2008). Against financial literacy education. Faculty Scholarship, Paper 199.

Available at http://scholarship.law.upenn.edu/ faculty_scholarship/199

Xia, T., Wang, Z., \& Li, K. (2014). Financial literacy overconfidence and stock market participation. Social Indicators Research, 119(3), 1233-1245. https://doi.org/10.1007/s11205-013-0555-9

Xu, Y., Beller, A. H., Roberts, B. W., \& Brown, J. R. (2015). Personality and young adult financial distress. Journal of Economic Psychology, 51, 90-100.https://doi.org/10.1016/j.joep.2015.08.010

Yang, B., Lester, D., \& Spinella, M. (2009). Personality correlates of financial behavior. Psychological reports, 104(3), 723-724. https://doi.org/10.2466/ PR0.104.3.723-724 


\section{Dodatak}

Tablica A

Zadaci koji su mjerili OECD financijsko znanje

\section{Zadatak}

Točan odgovor (gdje je ponuđeno više odgovora, točan odgovor je naglašen.

1. Zamislite da je neka osoba dobila poklon od $1000 \mathrm{kn}$, ali treba čekati godinu dana prije nego može koristiti novac, pri čemu je stopa inflacije 5 posto. Za tih godinu dana bit će u mogućnosti kupiti:

2. Posudili ste prijatelju $100 \mathrm{kn}$ jedne večeri i on vam idući dan vraća 100 kn. Koliku je kamatu vaš prijatelj platio na ovu pozajmicu?

3. Pretpostavimo da 1000 kuna stavite na štedni račun uz garanciju od 2 posto godišnje kamatne stope. Na račun ne stavljate više nikakav novac niti ga povlačite (banka ne računa nikakvu naknadu). Koliko će na računu biti novaca nakon jedne godine nakon što je uplaćena kamata?

4. Koliko će na tom računu biti novaca na kraju pet godina?

5. Investicija s velikim povratom je najvjerojatnije visokorizična.

6. Visoka inflacija znači da se životni troškovi ubrzano povećavaju.
a) Više nego prije
b) Jednako kao prije
c) Manje nego prije
d) Ovisi o tome što će se kupovati

0 kuna

\section{0 kuna}

a) Više od 1100 kuna

b) Točno 1100 kuna

c) Manje od 1100 kuna

\section{b) Točno}
a) Netočno

b) Točno

7. Manje je vjerojatno da ćete izgubiti sav novac ako štednju stavite na više od jednog mjesta.

a) Netočno

b) Točno

Tablica B

Zadaci koji su mjerili OECD Financijsko ponašanje

\section{Zadatak}

1. Prije kupovine pažljivo razmatram mogu li to sebi priuštiti.

2. Plaćam račune na vrijeme.

3. Vrlo pazim na svoje financije.

4. Postavljam dugoročne financijske ciljeve i nastojim in dostići.

5. U posljednjih 12 mjeseci jeste li (osobno) štedjeli novac na bilo koji od sljedećih načina? Uplaćivanje na štedni račun, dao/dala novac obitelji da štedi za mene, kupio/la financijsk investicijski proizvod kao npr. dionice, obveznice, u nekom drugom obliku (uključujući kupovinu nekretnine ili slično; ponuđeni odgovori su bili i štednja gotovine kod kuće ili u novčaniku te povećanje iznosa na tekućem računu, no ti odgovori nisu uključeni u aktivnu štednju).

6. Koja od sljedećih izjava najbolje opisuje način na koji ste zadnji put odabrali financijski proizvod? Razmatrao/la sam više proizvoda nekoliko različitih tvrtki; razmatrao/la sam nekoliko proizvoda jedne tvrtke.

7. U proteklih 12 mjeseci, jeste li osobno uzimali kredit (odnosno koristili dozvoljeno prekoračenje), te platili kamatu za neku od sljedećih namjena (pokrivanje životnih troškova)?

8. Tko je odgovoran za svakodnevne odluke vezane uz novac? Ima li vaše kućanstvo budžet? 


\title{
Summary
}

\section{WHAT DETERMINES FINANCIAL LITERACY? IN SEARCH OF RELEVANT DETERMINANTS}

\author{
Nikola Erceg, Zvonimir Galić \\ Department of Psychology, Faculty of Humanities and Social Sciences of Zagreb, \\ University of Zagreb, Zagreb, Croatia
}

\section{Maja Vehovec}

The Institute of Economics Zagreb, Zagreb, Croatia

Considering the increasing complexity, as well as the increasing need for financial products, it appears that the adequate levels of financial literacy are necessary. The research of the determinants of financial literacy of citizens is scarce in Croatia. Therefore, through this research we wanted to examine the increasing number of financial constructs with regard to the existing previous research, as well as determine the importance of socio-demographic factors in explaining financial literacy. The research was conducted on the representative sample of the citizens of the Republic of Croatia $(N=1049)$. The results have shown that socio-demographic variables represent a significant predictor of financial literacy, as well as its components, namely knowledge, attitudes and behaviour. The paper examines the importance of different socio-demographic characteristics and concludes that, although they are significant, socio-demographic variables are probably not the most important determinants of financial outcomes. Therefore, a greater emphasis on additional, psychological characteristics as potential determinants of financial outcomes is recommended.

Key words: financial literacy, financial knowledge, financial attitude, financial behaviours. 